\title{
EFFECT OF MODIFICATION OF MONGOLIAN NATURAL ZEOLITES ON ADSORPTION OF CHROMIUM FROM AQUEOUS SOLUTION
}

\author{
Bolortamir. Ss $^{1}$, Habaki.H ${ }^{2}$, Egashira. ${ }^{2}$ \\ ${ }^{1}$ - Mongolian Academy of Sciences \\ ta1mka@yahoo.com \\ ${ }^{2}$-Department of International Development Engineering, \\ Tokyo Institute of Technology
}

\begin{abstract}
Removal of chromium (Cr (III) ) as well as hexavalent chromium (Cr (VI) ) from tannery wastewater at same time by adsorption using Mongolian natural zeolite was studied in terms of the characteristics, modification, and chromium adsorption performance of the zeolite.

The cation exchange capacity of the zeolite ranged from $37 \times 10^{-3}$ to $144 \times 10^{-3} \mathrm{eq} \cdot \mathrm{g}^{-1}$. From the results of phase identification and elemental analysis of the zeolite after modification run, the zeolite was not decomposed and was modified successfully. The zeolites modified by $\mathrm{Ba}^{2+}, \mathrm{Cu}^{2+}$, and HDTMA-Br could adsorb $\mathrm{Cr}$ (III) as well as the unmodified one could. The higher $\mathrm{pH}$ gave the higher adsorption ability, similarly to the adsorption of $\mathrm{Cr}$ (VI). Consequently, this adsorption method with Mongolian natural zeolite was proposed to remove $\mathrm{Cr}$ (III) together with $\mathrm{Cr}$ (VI) from tannery wastewater at same time.

Keywords: Chromium, Adsorption, Mongolian Natural Zeolite, Zeolite Modification, Tannery Wastewater
\end{abstract}

\section{Introduction}

Chromium is one of the regulated toxic heavy metals in the environment. Chromium compounds are widely used in industries such as leather tanning, electroplating, manufacturing of dye, paint and paper. Chromium exists in the aqueous solution mainly in two states $\mathrm{Cr}$ (III) and $\mathrm{Cr}$ (VI). Cr (III) is extensively used in the tanning agent. Although $\mathrm{Cr}$ (III) is considerably less toxic than $\mathrm{Cr}$ (VI), its disposal as a dissolved species in natural waters or as sludge in soils may pose serious health risks because it can be oxidized to $\mathrm{Cr}(\mathrm{VI})$ in the environment [1].

In Ulan Bator, water resource pollution by hexavalent and trivalent chromiums $(\mathrm{Cr}$ (VI), Cr (III)) in wastewater from tannery, which is one of the most important industries in Mongolia, becomes serious. In the fact, in Mongolia, there are plenty of natural zeolite deposits, although these resources are not sufficiently exploited and studied yet. The most common, stable and abundant forms are hexavalent (Cr (VI) ) and trivalent (Cr (III) ) 
chromiums. There has been various works studying the removal of chromium $(\mathrm{Cr})$ from aqueous solution by adsorption using natural zeolite. The zeolite modified by $\mathrm{Ba}^{2+}$ could adsorb and favorably remove $\mathrm{Cr}(\mathrm{VI})$, which exists as chromate anion in aqueous solution, whereas the unmodified one could not [1], due to the zeolite surface is charged negatively. On the contrary, $\mathrm{Cr}$ (III) forms cation in aqueous solution.

In this study, removal of $\mathrm{Cr}$ (III) as well as $\mathrm{Cr}$ (VI) from tannery wastewater at same time by adsorption using Mongolian natural zeolite was studied in terms of the characteristics, modification, and chromium adsorption performance of zeolite.

\section{Experimental}

The natural zeolite samples obtained from Tsagaan Tsav and Urgon deposit in Mongolia. In previous study reported that five kinds of natural zeolite used for modification and adsorption run. These samples have different base components in their content and different porous properties. The detailed information of Mongolian natural zeolites is shown in Table 1 [1]

The principal conditions of zeolite modification are shown in Table 2. The zeolite samples and the aqueous solution of $\mathrm{Ba}^{2+}[1,2], \mathrm{Cu}^{2+}[2]$, or HDTMA- $\mathrm{Br}$ [3] were brought into contact with each other to modify the samples. The modified samples were washed twice and dried. Thus obtained samples with and without modification were kept in a desiccator before in characterization and adsorption. The element composition on the zeolite surface was determined by energy dispersive X-ray fluorescence spectrometry (EDX) and the modification of zeolite samples with $\mathrm{Ba}^{2+}$ was characterized by XRD to know that after modification zeolite samples based component. The cation exchange capacities (CEC) of the zeolites were measured by the method of US-EPA Method 9081[4].

The principal conditions of batch adsorption run are summarized in Table 3 . $\mathrm{Cr}\left(\mathrm{NO}_{3}\right)_{3} \times 9 \mathrm{H}_{2} \mathrm{O}$ was used as a source of $\mathrm{Cr}$ (III). The respective aqueous solutions were analyzed by $\mathrm{pH}$ meter and ICP spectrometer.

Table 1 Principal characteristics of Mongolian natural zeolites

\begin{tabular}{lllccc}
\hline Sample & Deposit [1] & $\begin{array}{c}\text { Base component } \\
\text { (by XRD) }[1]\end{array}$ & $\begin{array}{c}\text { Surface area } \\
{\left[\mathrm{m}^{2} \cdot \mathrm{g}^{-1}\right][1]}\end{array}$ & $\begin{array}{c}\text { Pore volume } \\
{\left[\mathrm{m}^{3} \cdot \mathrm{g}^{-1}\right][1]}\end{array}$ & $\begin{array}{c}\text { Cation exch.cap. } \\
(\text { C.E.C. })\left[\mathrm{eq} \cdot \mathrm{g}^{-1}\right]\end{array}$ \\
\hline NZ-1 & Tsagaan Tsav & mordenite etc. & 26 & $0.041 \times 10^{-6}$ & $74 \times 10^{-3}$ \\
NZ-2 & Tsagaan Tsav & gismondine etc. & 36 & $0.065 \times 10^{-6}$ & $54 \times 10^{-3}$ \\
NZ-3 & Tsagaan Tsav & clinoptilolite etc & 15 & $0.027 \times 10^{-6}$ & $100 \times 10^{-3}$ \\
NZ-4 & Tsagaan Tsav & chabazite etc. & 159 & $0.082 \times 10^{-6}$ & $37 \times 10^{-3}$ \\
NZ-5 & Urgon & clinoptilolite etc. & 43 & $0.096 \times 10^{-6}$ & $144 \times 10^{-3}$ \\
\hline
\end{tabular}


Table 2 Principal conditions of zeolite modification by

\begin{tabular}{|c|c|}
\hline \multicolumn{2}{|c|}{$\mathrm{Ba}^{2+}, \mathrm{Cu}^{2+}$, and HDTMA-Br } \\
\hline Zeolite & Mongolian natural zeolite (see Table 1) \\
\hline Mass of zeolite [g] & $20 ; 50$ \\
\hline Modification solution & $\begin{array}{c}\text { aqueous solution of metal cation } \\
\left(\mathrm{Ba}^{2+}, \mathrm{Cu}^{2+}\right) ; \text { surfactant (HDTMA-Br) }\end{array}$ \\
\hline $\begin{array}{l}\text { Concentration of modifier in } \\
\text { modification solution }\left[\mathrm{mol} \cdot \mathrm{m}^{-3}\right]\end{array}$ & $0.05 \times 10^{3} ; 0.13 \times 10^{3}$ \\
\hline $\begin{array}{l}\text { Volume of modification solution } \\
\text { to mass of zeolite }\left[\mathrm{m}^{3} \cdot \mathrm{g}^{-1}\right]\end{array}$ & $3 \times 10^{-6} ; 10 \times 10^{-6}$ \\
\hline Temperature $[\mathrm{K}]$ & $333 ; 298$ \\
\hline Time $[\mathrm{h}]$ & $168 ; 24$ \\
\hline Table 3 Principal exp & nental conditions of adsorption run \\
\hline Feed solution & Aqueous solution of $\mathrm{Cr}\left(\mathrm{NO}_{3}\right)_{3} \times 9 \mathrm{H}_{2} \mathrm{O}$ \\
\hline Mass of feed solution, $L_{0}[\mathrm{~g}]$ & 50 \\
\hline $\begin{array}{l}\text { Mass fraction of chromium atom in } \\
\text { feed solution, } x_{0} \times 10^{6}[-]\end{array}$ & $10-100$ \\
\hline $\mathrm{pH}$ of feed solution, $\mathrm{pH}_{0}$ & $\begin{array}{c}2,3.5,5.5 \\
\text { (Adjusted by } \mathrm{HCl} \text { and } \mathrm{NaOH} \text { ) }\end{array}$ \\
\hline Adsorbent & $\begin{array}{c}\mathrm{NZ}-1,2,3,4,5 \text { (without or with } \bmod \mathrm{Ba}^{2+}, \mathrm{Cu}^{2+} \text {, } \\
\text { HDTMA-Br) }\end{array}$ \\
\hline $\begin{array}{l}\text { Mass ratio of adsorbent to feed solu- } \\
\text { tion, } S / L_{0}[-]\end{array}$ & 0.01 \\
\hline Contacting time, $t[\mathrm{~h}]$ & $\overline{7} \overline{2}^{-1}$ \\
\hline Contacting temperature $[\mathrm{K}]$ & 303 \\
\hline
\end{tabular}

\section{Results and Discussion}

Table 1 shows the cation exchange capacity (C.E.C) together with the previous results of base component, surface area, and pore volume of the zeolite[1]. The C.E.C ranged from $43 \times 10^{-3}$ to $144 \times 10^{-3} \mathrm{eq} \cdot \mathrm{g}^{-1}$.

Figure 1 shows the comparison between the element compositions on the surface of zeolite with and without modification by $\mathrm{Ba}^{2+}$. The content of $\mathrm{Ba}^{2+}$ in the modified zeolite was much higher than that in the unmodified one, similarly to the previous results[1], and the successful zeolite modification could be reconfirmed. 


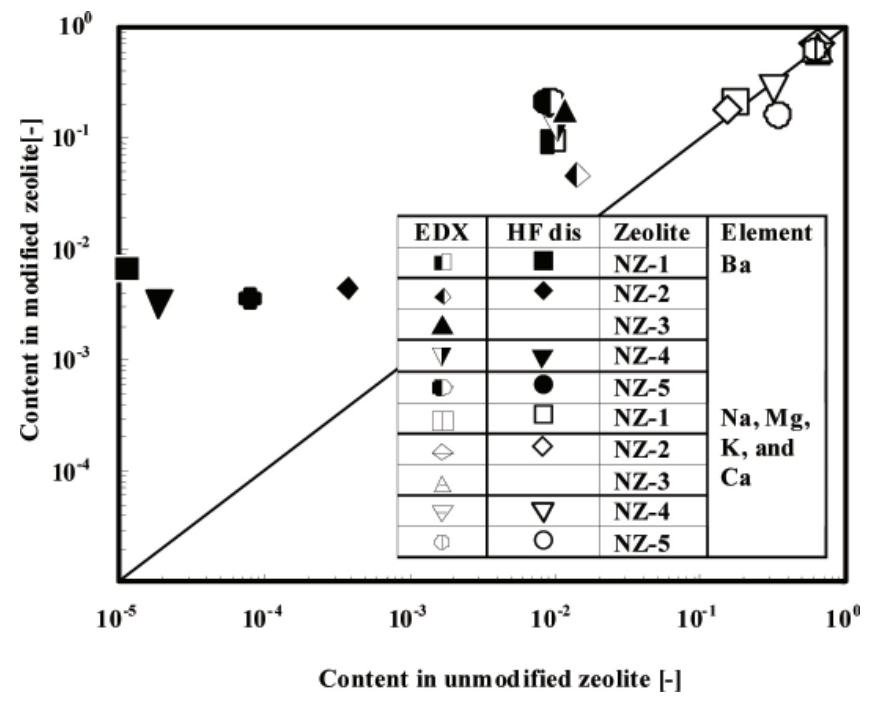

Figure 1 Comparison of element contents between surface of zeolite without and with modification by $\mathrm{Ba}^{2+}$

The result of XRD spectra of natural zeolite samples were before and after modification shown in Figure 2. The before and after zeolite modification with $\mathrm{Ba}^{2+}$, the spectra did not changed almost same as unmodified one. The zeolite were not decomposed with the modification solution.

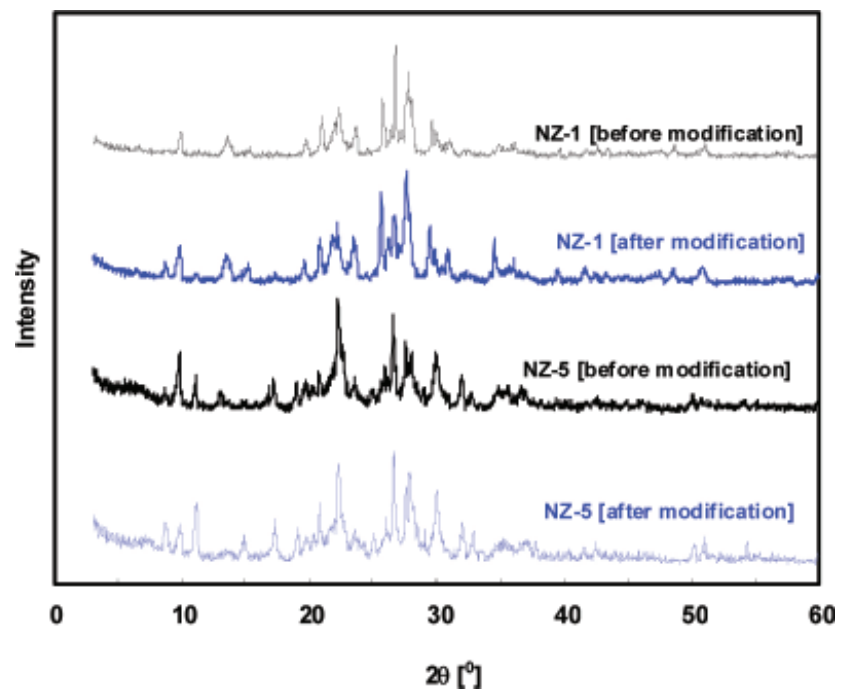

Figure 2 XRD spectra before and after modification of natural zeolite 
The adsorbed amount of $\mathrm{Cr}$ on zeolite, $q$, was calculated by the material balance relationship.

Figure 3 shows the effects of modifications on the adsorption isotherms of $\mathrm{Cr}$ (III) on the zeolite. The unmodified zeolite could adsorb $\mathrm{Cr}$ (III) as expected. Zeolites modified by $\mathrm{Ba}^{2+}, \mathrm{Cu}^{2+}$, and HDTMA-Br could also adsorb $\mathrm{Cr}$ (III), namely, $\mathrm{Cr}$ (III) would be removed by the modified zeolite as well as $\mathrm{Cr}$ (VI)[1] at same time. While the modifications with $\mathrm{Ba}^{2+}$ and $\mathrm{Cu}^{2+}$ did not affect the adsorption performances, the performance of the zeolite modified by HDTMA-Br was lower.

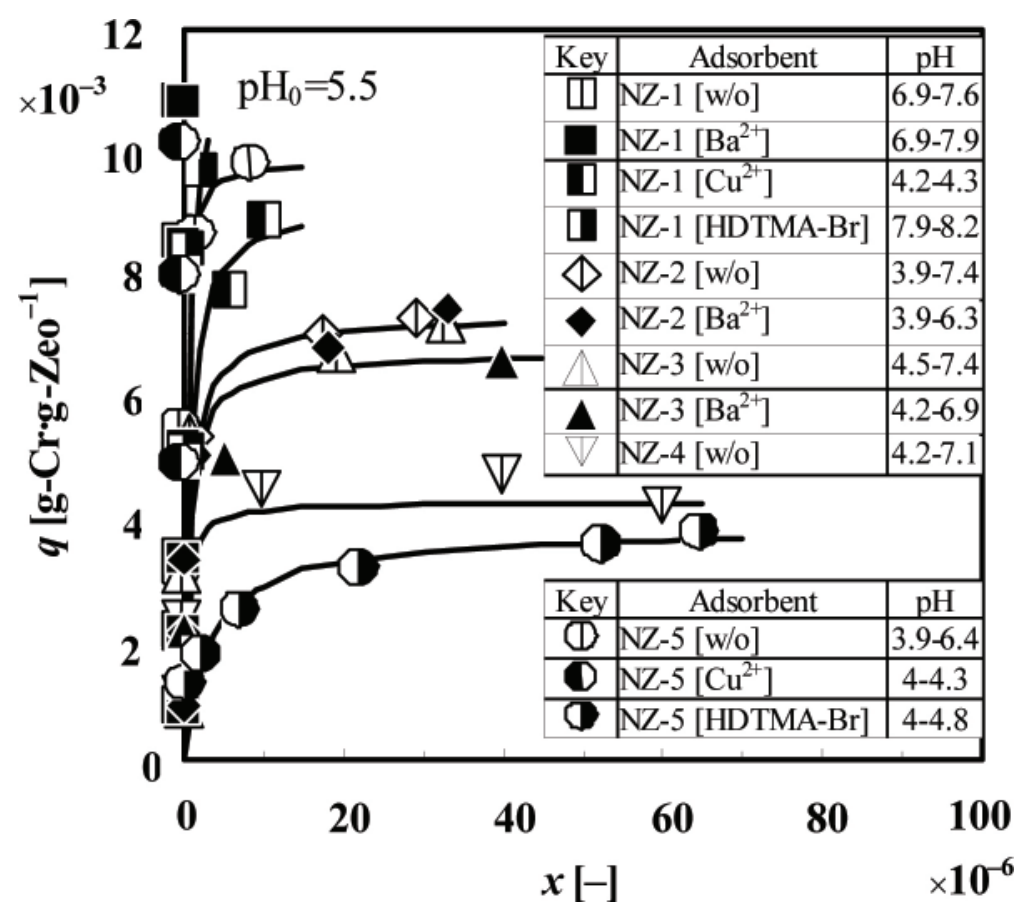

Figure 3 Effect of modification on adsorption isotherm of Cr (III) on Mongolian natural zeolite

In the solution of higher $\mathrm{pH}$ in this study, $\mathrm{Cr}(\mathrm{OH})^{2+}$ is dominant[5]. The adsorption isotherms were described by Langmuir equation. Figure 4 shows the saturated adsorption amount, $q^{*}$, and the adsorption coefficient, $K_{\mathrm{L}}$, are plotted the average of equilibrium $\mathrm{pH}$. The $q^{*}$ and $K_{\mathrm{L}}$ values increased with increasing $\mathrm{pH}$. 


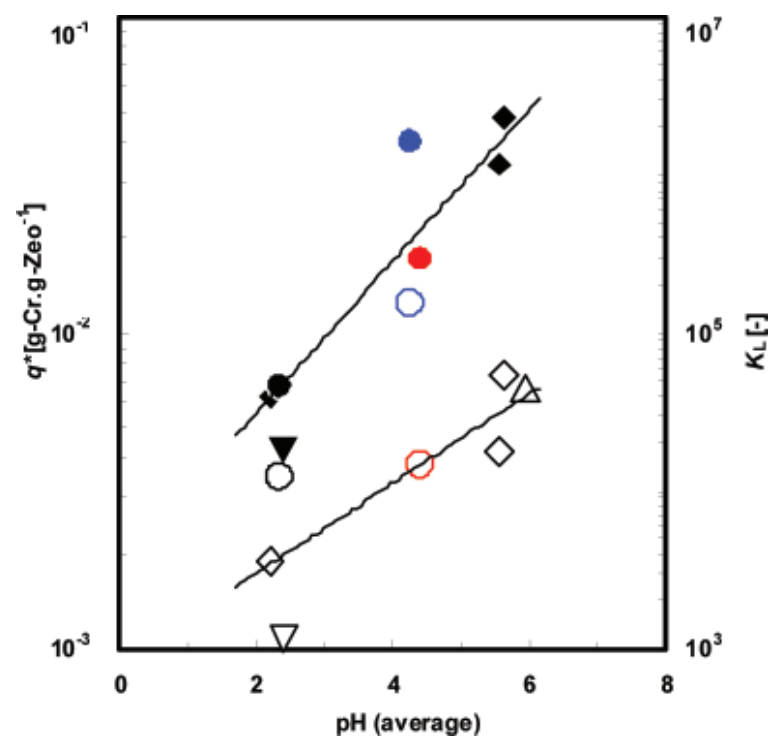

Figure 4 Effect of the $\mathrm{pH}$ of equilibrium solution on the saturated adsorption amount, $q^{*}$, and adsorption coefficient, $K_{\mathrm{L}}$, in Langmuir equation

Figure 5 shows the relation between $\mathrm{Cr}(\mathrm{VI})$ and $\mathrm{Cr}$ (III) adsorption parameters with $\mathrm{pH}$. The $K_{\mathrm{L}}$ adsorption parameters of $\mathrm{Cr}$ (III) much higher than that of $K_{\mathrm{L}}$ of $\mathrm{Cr}(\mathrm{VI})[1]$. The $q^{*}$ parameter were adsorption performances almost same as each other.

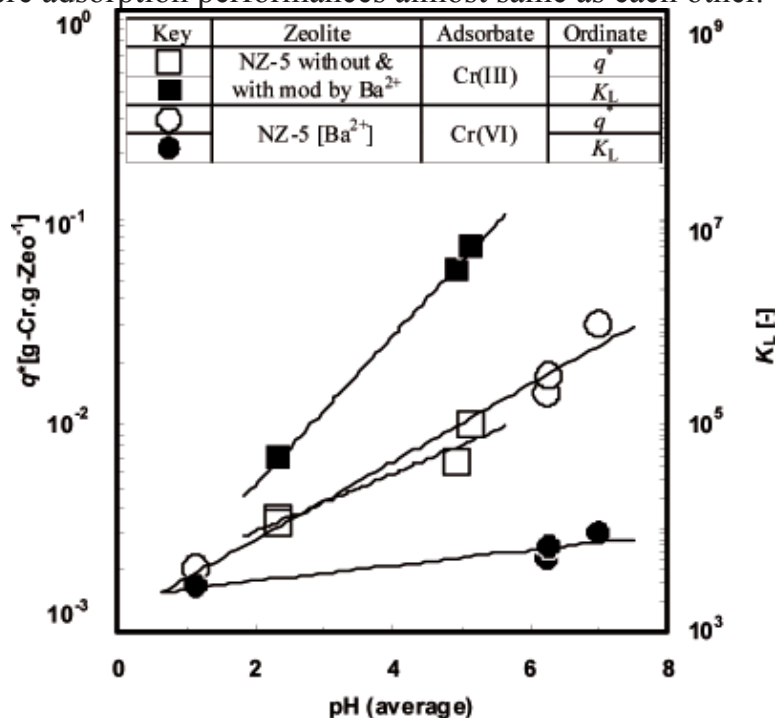

Figure 5 The relations between $\mathrm{Cr}(\mathrm{VI})$ and $\mathrm{Cr}$ (III) adsorption parameters with $\mathrm{pH}$ 


\section{Conclusions}

The cation exchange capacity of the zeolite ranged from $43 \times 10^{-3}$ to $144 \times 10^{-3} \mathrm{eq} \cdot \mathrm{g}^{-1}$. The zeolites modified by $\mathrm{Ba}^{2+}, \mathrm{Cu}^{2+}$, and HDTMA-Br could adsorb $\mathrm{Cr}$ (III) as well as the unmodified one could. The higher $\mathrm{pH}$ gave the higher adsorption ability. The $K_{\mathrm{L}}$ adsorption parameters of $\mathrm{Cr}$ (III) are much higher than that of $K_{\mathrm{L}}$ of $\mathrm{Cr}(\mathrm{VI})$. The $q^{*}$ parameters adsorption performances almost same as each other.

Consequently, the adsorption using Mongolian natural zeolite was proposed to remove $\mathrm{Cr}$ (III) together with $\mathrm{Cr}$ (VI) from tannery wastewater at same time.

Nomenclature

$K_{\mathrm{L}}=$ adsorption coefficient in Langmuir equation

$[-]$

$L_{0}=$ mass of solution

$[\mathrm{g}]$

$\mathrm{pH}=\mathrm{pH}$ in solution

$q=$ adsorption mass of chromium atom per unit mass of adsorbent $\quad\left[\mathrm{g}-\mathrm{Cr} \cdot \mathrm{g}-\mathrm{Zeo}{ }^{-1}\right.$ ]

$q^{*}=$ saturated adsorption mass of chromium atom per unit mass of adsorbent in Langmuir equation

$\left[\mathrm{g}-\mathrm{Cr} \cdot \mathrm{g}-\mathrm{Zeo}^{-1}\right]$

$S=$ mass of adsorbent

$x=$ mass fraction of chromium atom in solution

[g]

$[-]$

References

[1] Bolortamir, Ts. and Egashira, R., J. Chem. Eng. Japan, 41 (10) 1003 - 1009 (2008)

[2] Faghihian, H. et al.; Water Research, 39, 1099 (2005)

[3] Haggerty, G. M. et al.; Environ. Sci. Technol., 28, 452 (1994)

[4] Chapman, H.D.,»Cation-exchange Capacity,» pp. 891-900, in C.A. Black (ed.), Method of Soil Analysis, Part 2: Chemical and Microbiological Properties, Am. Soc. Agron., Madison, Wisconsin (1965).

[5] Rai, D. et al.; Inorg. Chem, 26, 345 (1987) 